\title{
Corium tissue expression of genes associated with inflammation, oxidative stress, and keratin formation in relation to lameness in dairy cows ${ }^{1}$
}

\author{
J. S. Osorio, ${ }^{*}$ B. C. Fraser,† D. E. Graugnard, ${ }^{\star}$ S. S. Singh, $\ddagger$ J. K. Drackley, ${ }^{\star}$ E. F. Garrett,‡ and J. J. Loor ${ }^{* 2}$ \\ *Department of Animal Sciences, University of Illinois, 1207 West Gregory Drive, Urbana 61801 \\ †College of Veterinary Medicine, Kansas State University, 1800 Dennison Ave., Manhattan 66502 \\ $\ddagger$ College of Veterinary Medicine, University of Illinois, 1008 W. Hazelwood Drive, Urbana 61802
}

\section{ABSTRACT}

Objectives were to (1) determine the feasibility of performing hoof biopsies without impairing locomotion; (2) evaluate the feasibility of using biopsied tissue for quantitative PCR; and (3) compare relative gene expression among claws for several target genes. Biopsies were performed on 6 Holstein cows, yielding 4 tissue specimens per cow from front leg, right limb, and medial claw (claw position 3); rear leg, left limb, and lateral claw (claw position 5); and rear leg, right limb, medial claw (claw position 7). Cows were monitored for lameness daily for $7 \mathrm{~d}$ post-biopsy and then weekly for 8 wk. Histopathological analysis confirmed that tissue collected was from between the stratum corneum and dermis. Biopsied tissue was used for RNA extraction, including evaluation of yield and purity. The profile by claw position of 19 genes with key functions in cell differentiation, proliferation, inflammation, and keratin formation was assessed via quantitative reverse transcription-PCR. Other than transient disturbances in locomotion score in some cows during 2 to $4 \mathrm{~d}$ postbiopsy, no signs of pain, locomotion impairment, or clinical lameness were observed post-biopsy. Total RNA yields averaged $259.7 \pm 100,447.8 \pm 288$, and 496.4 $\pm 118 \mu \mathrm{g} / \mathrm{mg}$ of tissue for claw positions 3,5 , and 7 , respectively. The biopsy procedure was successful for obtaining corium for gene expression. Among 5 keratin proteins analyzed, only keratin 5 was expressed. Transcripts related to inflammation and oxidative stress (STAT3, MYD88, SOD2, and TLR4) were among the more abundant in corium tissue, but expression did not differ between claws. Biotinidase $(B T D)$ expression was greater in claw 3 versus claw 5 , whereas the ligandactivated nuclear receptor retinoic acid receptor- $\alpha$ $(R X R A)$ was greater in claws $3+5$ compared with claw 7 . Overall, results from this pilot study revealed

\footnotetext{
Received November 13, 2011.

Accepted May 30, 2012.

${ }^{1}$ Supported in part by Hatch funds under project ILLU-538-326 (National Institute of Food and Agriculture).

${ }^{2}$ Corresponding author: jloor@illinois.edu
}

modest differences at the transcriptome level, suggesting that biotin availability and lipid metabolism differ between claw positions, whereas inflammation and oxidative stress seem to play an important role across claws. More comprehensive studies of the hoof transcriptome are required to improve our understanding of the mechanisms that link environmental and dietary factors to development of lameness.

Key words: laminitis, gene expression, biopsy

\section{INTRODUCTION}

According to the National Animal Health Monitoring System (NAHMS), lameness is one of the most common health problems and the first cause of death in dairy cows (USDA, 2007). Besides representing a significant economic loss for dairy producers, lameness is an important animal welfare issue (Neveux et al., 2006). Hoof diseases can be caused by environmental and dietary factors such as floor system, season, hoof trimming, and dietary carbohydrate overload. The incidence and severity of lameness is often assessed through hoof appearance and behavioral indicators, including time budget and locomotion score (Norring et al., 2008; Danscher et al., 2009).

Epidermal tissue formation of the hoof is affected by changes in the keratinization process or keratin protein formation (Tomlinson et al., 2004). Keratinization involves the progressive replacement of most of the cell contents by keratin proteins (Hendry et al., 1997). The differing isoelectric points of cytokeratins (CK) allow them to form stable macromolecular structures by the heterodimerization of 2 molecules (one of each type) to form a coiled dimer, which then complexes with another dimer to form a 4-polypeptide complex (Hendry et al., 1997). According to Hendry et al. (2001), the most abundant CK in healthy bovine hoof tissue were CK4, 5/6, 10, and 14. Cytokeratin 16 was present in diseased claws but not in healthy claws. In addition, the distribution of CK within the tissue was altered in claws with sole ulcer. Damage of the corium, as in sole ulceration (Hendry et al., 2001) and subclinical laminitis, not only affects the expression of some CK but 
also triggers changes associated with inflammation and oxidative stress. Failing to produce sufficient, specific keratin protein might compromise the optimal production of the macromolecular structures described above and eventually impair total hoof conformation.

Inflammation as a result of pathological, nutritional, or environmental stress increases plasma concentrations of endotoxins, histamine, and tumor necrosis factor- $\alpha$ (Bailey et al., 2009), all of which may cause vascular constriction, dilatation, or shunting within the hoof, leading to hypoxia in the corium tissue. At the molecular level, this could affect or modify how cells respond to inflammation or oxidative stresses. Recent work evaluating cytokine mRNA expression in laminar tissue from horses demonstrated increased expression of cytokines following carbohydrate overload, with the increase in cytokine expression occurring near the onset of lameness (Faleiros et al., 2011; Leise et al., 2011). This recent work on horses further establishes the link between nutrition and inflammatory changes in the laminar tissues and highlights the temporal shifts in cytokine expression during the onset of laminitis. Similar cytokine expression and temporal relationships may exist in cattle but species differences are too significant to permit direct extrapolation. Basal expression of genes associated with corium tissue formation, inflammation, and oxidative stress may differ depending on claw length and growth rate. In dairy cattle, claw length and growth rates vary between claws of the same animal. Specifically, the rear lateral claws tend to grow faster than other claws, especially when animals are housed in confinement on concrete. This pattern in growth rate has been associated with differences in weight bearing among claws (Toussiant, 1989; van der Tol et al., 2002; Muggli et al., 2011) because the lateral rear and front medial claws bear more weight than the contralateral claws during the normal walking stride. These differences in weight bearing, also known as "claw asymmetry," have been related to negative performance in dairy cows (Capion et al., 2008).

A technique has been described for serial sampling of laminar tissue in the conscious horse without adverse effects on the animal (Hanly et al., 2009) and the tissue collected was suitable for mRNA expression analysis. A biopsy technique for laminar tissue biopsy in conscious cattle has also been described (Singh et al., 1993, 1994) but no molecular analysis of the tissue samples was attempted. A technique that allows serial sampling of the laminar tissue in cattle for gene expression analysis could significantly improve our understanding of the dynamic changes in the bovine hoof when exposed to different dietary or environmental conditions.

The hypothesis of this study was that expression of mRNA for CK and inflammatory cytokines is differ- ent between claws of the same animal. The specific objectives were (1) to determine the feasibility of performing hoof biopsies without impairing locomotion or inducing pathological alterations of affected tissues; (2) to evaluate the feasibility of using biopsied tissue for quantitative PCR (qPCR) by analyzing quantity and purity of extracted RNA; and (3) to compare relative gene expression of genes involved in cell differentiation, proliferation, inflammation, and keratin formation by claw position. If successful, the technique could be used to study the temporal changes in mRNA expression in hooves of cattle exposed to differing environmental or dietary treatments.

\section{MATERIALS AND METHODS}

Six nonlactating and nonpregnant Holstein cows from the University of Illinois dairy herd were used in the experiment. All animal procedures were conducted under protocols approved by the University of Illinois Institutional Animal Care and Use Committee. Cows were restrained in lateral recumbence on a hydraulic tilt table or in a standing hoof-trimming chute. Two biopsies were collected under local anesthesia from each of the following claw positions: 3,5 , and 7 , according to Figure 1. Each of the samples was used for either mRNA extraction or histopathology examination. The array of leg-claw combinations was selected to allow evaluation of the effect of claw symmetry (e.g., susceptible claws 3 and 5 vs. nonsusceptible claw 7 ) on mRNA expression.

The hair of the pastern was clipped and the dorsal and abaxial wall of the claw and pastern area was cleaned with povidone iodine scrub (catalog no. 2565541-8, Durvet Inc., Blue Springs, MO), allowing $3 \mathrm{~min}$ of contact time. All biopsy instruments remained in an antiseptic solution until time of use. A tourniquet was applied midway between the fetlock and tarsus/ carpus of each limb chosen for biopsy. Local anesthesia was accomplished by injecting approximately $5 \mathrm{~mL}$ of $2 \%$ lidocaine-HCl (Agri Laboratories, St. Joseph, MO) in each of the following nerves: (1) front limb: axial and abaxial dorsal nerve and axial and abaxial palmar nerve of the same digit; (2) hind limb: axial and abaxial dorsal proper nerve and axial and abaxial plantar proper nerve of the same digit.

After confirming that anesthesia was successful, the dorsal hoof wall on each of the claws was perforated in 2 locations using a $12-\mathrm{mm}$ drill bit. The hoof horn overlying the biopsy site was removed with the drill bit until 1 to $2 \mathrm{~mm}$ of hoof wall remained. The optimal depth was assessed by the change in the ease of passage of the drill bit through the hoof and by resistance of the hoof horn to pressure (Figure 2A). A 6-mm biopsy 


\section{HEAD}
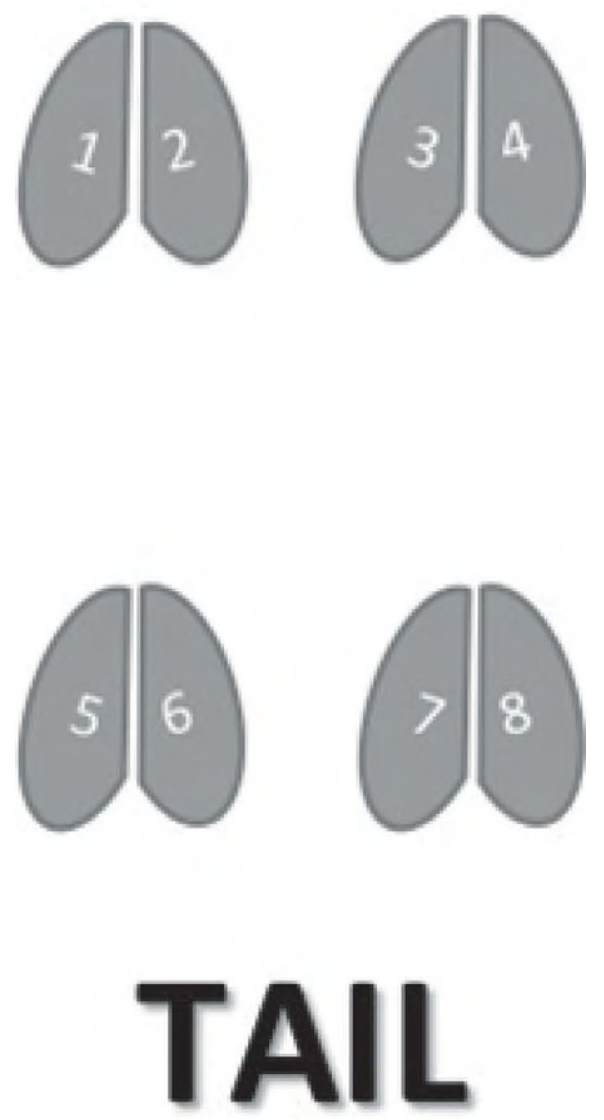

Figure 1. Nomenclature used to depict each claw within each hoof: (1) front left lateral, (2) front left medial, (3) front right medial, (4) front right lateral, (5) rear left lateral, (6) rear left medial, (7) rear right medial, and (8) rear right lateral.

punch (catalog no. HL-BP99, MedExSupply, Monsey, NY) was inserted through the hole and used to cut through the remaining hoof wall and the underlying corium. The biopsy instrument was then rotated 2 to 3 times to cut through the tissue (Figure 2B). Forceps and a scalpel blade were used to sever the laminar corium and remove the biopsy specimen. Sterile dry gauze was applied to the biopsy site and held in place with tape. Flunixin meglumine $(1.1 \mathrm{mg} / \mathrm{kg}$ i.v.; catalog no. R32000, KV Supply, David, NE) was administered immediately following the procedure. Cows were monitored daily for signs of lameness, and a locomotion score was recorded, based on the locomotion score scale described by Flower and Weary (2006), daily for $7 \mathrm{~d}$ after biopsy and then weekly for $8 \mathrm{wk}$.

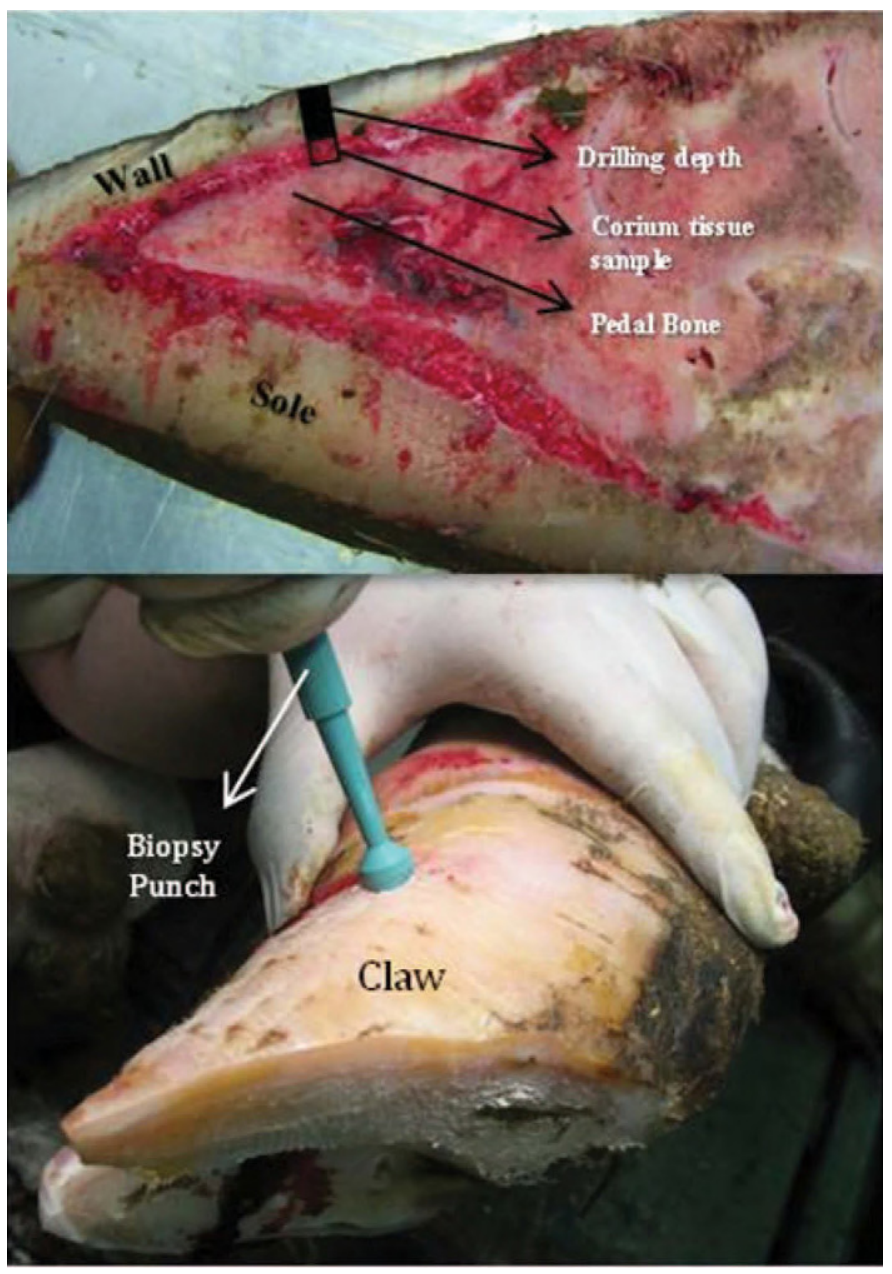

Figure 2. (A) Biopsy drilling depth and visual of corium in a transverse cut section of a claw; (B) harvesting of biopsy sample with a 6-mm biopsy punch. Color version available in the online PDF.

\section{Histopathology}

The samples for histologic examination were fixed in $10 \%$ buffered formalin immediately after harvesting. The samples were trimmed manually, processed through a graded series of alcohol for dehydration, and stained with hematoxylin and eosin for routine histologic examination. Two slides per paraffin block were used and each slide had double recuts of the biopsy sample obtained at different levels from each paraffin block. Histologically healthy hoof comprises stratum corneum; primary epidermal laminae, which includes stratum germinativum, stratum spinosum, and stratum corneum; primary dermal laminae; and dermis. Each hoof biopsy sample was evaluated for the presence of superficial stratum corneum, primary epidermal laminae, primary dermal laminae, dermis, and third phalanx (Figure 3). 


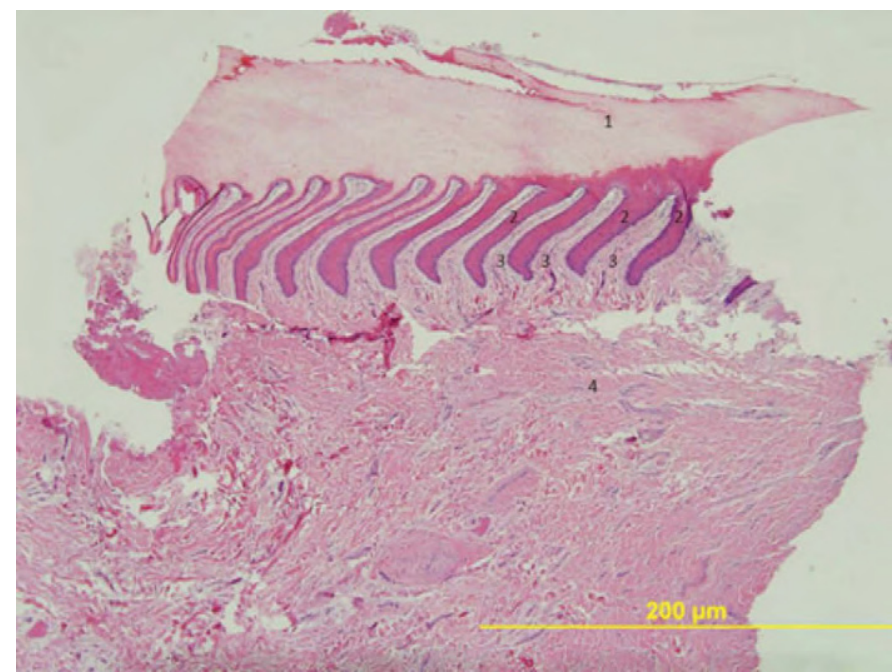

Figure 3. Representative histology of a bovine claw sample. Claw wall is made of stratum corneum (1), primary epidermal laminae (2), primary dermal laminae (3), and the dermis (4). Color version available in the online PDF.

\section{RNA Isolation and Reverse Transcription-qPCR}

Immediately after harvest, the biopsy specimens were placed in 2 vials and stored in liquid nitrogen until analysis. Biopsy tissue samples were weighed and tissue was immediately subjected to RNA extraction using ice-cold Trizol (Invitrogen Corp., Carlsbad, CA) as described by Loor et al. (2005). Genomic DNA was removed from RNA with DNase using RNeasy Mini Kit columns (Qiagen, Hilden, Germany). The RNA concentration was measured using a Nanodrop ND-1000 spectrophotometer (NanoDrop Technologies, Wilmington, DE). Purity of RNA (absorbance at $260 \mathrm{~nm}: 280 \mathrm{~nm}$ ) was $>2.0$ for all samples.

We selected genes for the study based on biological functions that could be of importance for hoof tissue growth, development, and response to cytokines that may be upregulated in response to dietary changes, environmental changes, or disease (Table 1). Also of interest were transcription factors whose function could be affected by nutrients such as long-chain fatty acids, vitamins, or minerals. We focused on peroxisome proliferator-activated receptor (PPAR) isoforms that have been shown to control several target genes associated with inflammation and metabolism in bovine cells (Bionaz et al., 2012). Additional genes of interest were neutral-basic and acidic keratin proteins, also known as type I and type II keratins (Omary et al., 2009), and genes involved in biotin recycling, cell growth, inflammation, and oxidative stress.

Synthesis of cDNA, qPCR, primer design (Table 2), and primer testing were performed using protocols pre- viously reported by Graugnard et al. (2010). Quantitative reverse transcription (RT)-PCR efficiency for most genes was similar to that observed previously by Mills et al. (2009) in epidermal-dermal tissue from bovine claw. The final gene expression data were normalized using the geometric mean of GAPDH, RPS9, and UXT, which have been verified previously as suitable internal control genes (ICG; Bionaz and Loor, 2007). Normalized data using the geometric mean of the ICG were log-transformed $\left(\log _{2}\right.$ scale) before statistical analysis using the MIXED procedure of SAS (version 9.2, SAS Institute Inc., Cary, NC). Claw position was used as the fixed effect and cow was designated as a random effect in the model. Statistical differences were declared at $P \leq 0.06$. Log-transformed results were subjected to contrasts comparing (1) claw 3 versus claw 5, and (2) claws $3+5$ versus claw 7 . A fold difference in mRNA expression between each susceptible claw (3 or 5 ) over the nonsusceptible claw (7) was calculated to compare the relative abundance of selected genes. Statistical analysis of these responses was not conducted because it would not have yielded biologically meaningful results.

\section{RESULTS AND DISCUSSION}

Results for locomotion scores during the $7 \mathrm{~d}$ following biopsy are presented in Table 3. Locomotion scores before biopsy were normal (i.e., locomotion score $=1$ ) for all cows. Locomotion score was affected primarily during d 2 to 4 after biopsy, during which time 1 of the 6 cows had a locomotion score of 3 (Table 3). However, all cows returned to a normal locomotion score by $7 \mathrm{~d}$ without further locomotion impairment observed (data not shown) in the subsequent 8 wk of observation. The biopsy procedure caused only minor, transient changes in locomotion score and did not cause any chronic or permanent damage to the hoof. Thus, it would be safe to repeat this procedure in an animal to study temporal changes in hoof tissues.

Nine biopsy samples out of 10 used for the histologic analysis had demonstrable primary epidermal and primary dermal laminae and dermis; a representative tissue section is depicted in Figure 2. In primary epidermal laminae, all 3 layers including stratum germinativum, stratum spinosum, and stratum corneum were clearly visible. Superficial stratum corneum was visible in 8 samples. This confirmed that the described hoof biopsy technique could be used to effectively collect tissue of the hoof where important physiological changes such as cell differentiation, keratinization, and cornification take place.

The amount of laminar tissue harvested with the hoof biopsy technique is listed in Table 4. Purity of 
Table 1. Genes studied and their biological functions

\begin{tabular}{|c|c|c|}
\hline Symbol & Name & Biological function and process \\
\hline SOD2 & Superoxide dismutase 2 & $\begin{array}{l}\text { It destroys radicals, which are normally produced within the cells and that are toxic to } \\
\text { biological systems }\end{array}$ \\
\hline PTGS2 & $\begin{array}{l}\text { Prostaglandin-endoperoxide } \\
\text { synthase } 2\end{array}$ & $\begin{array}{l}\text { May have a role as a major mediator of inflammation or for prostanoid signaling in } \\
\text { activity-dependent plasticity }\end{array}$ \\
\hline PPARG & $\begin{array}{l}\text { Peroxisome proliferator-activated } \\
\text { receptor } \gamma\end{array}$ & Regulator of adipocyte differentiation \\
\hline PPARA & $\begin{array}{l}\text { Peroxisome proliferator-activated } \\
\text { receptor } \alpha\end{array}$ & $\begin{array}{l}\text { PPAR- } \alpha \text { is a member of the nuclear receptor family of ligand-activated transcription } \\
\text { factors that heterodimerize with the retinoic X receptor (RXR) to regulate gene expression }\end{array}$ \\
\hline RXRA & Retinoid $\mathrm{X}$ receptor, $\alpha$ & $\begin{array}{l}\text { Commonly binds to many other nuclear receptors, including PPAR, liver X receptors } \\
\text { (LXRs) and vitamin D receptors (VDR) to regulate other genes }\end{array}$ \\
\hline STAT3 & $\begin{array}{l}\text { Signal transducer and activator } \\
\text { of transcription } 3\end{array}$ & $\begin{array}{l}\text { Transcription factor that binds to the IL-6-responsive elements identified in the promoters } \\
\text { of various acute-phase protein genes; activated by IL31 through IL31RA }\end{array}$ \\
\hline KLF10 & Krüppel-like factor 10 & Transcriptional repressor involved in the regulation of cell growth; inhibits cell growth \\
\hline BTD & Biotinidase & Involved in biotin recycling and accretion of free biotin in the body \\
\hline KRT2 & Keratin 2 & Type II cytokeratin, found in the upper spinous layer of epidermal keratinocytes \\
\hline KRT4 & Keratin 4 & $\begin{array}{l}\text { Type II cytokeratin, found in mucosal and esophageal epithelial cells together with keratin } \\
13\end{array}$ \\
\hline KRT5 & Keratin 5 & Type II cytokeratin, found in basal layers of the epidermis and associated with keratin 14 \\
\hline KRT13 & Keratin 13 & $\begin{array}{l}\text { Type I cytokeratin, expressed in the suprabasal layer of noncornified stratified epithelial } \\
\text { cells and is usually paired to keratin } 4\end{array}$ \\
\hline KRT14 & Keratin 14 & $\begin{array}{l}\text { Type I cytokeratin, component of cytoskeleton and usually found as a heterotetramer with } \\
2 \text { keratin } 5 \text { molecules }\end{array}$ \\
\hline
\end{tabular}

${ }^{1}$ Entrez Gene; National Center for Biotechnology Information (http://www.ncbi.nlm.nih.gov/gene).

RNA was within an adequate range compared with that observed in previous work with other bovine tissues (Bionaz and Loor, 2007; Graugnard et al., 2010). Purification of RNA during the Trizol extraction procedure removes protein, phenol, and other contaminants that absorb strongly at or near $280 \mathrm{~nm}$ (see manufacturer's protocol). Use of acid-phenol chloroform removes any residual DNA during the extraction process. Although the concentration of RNA from claw 3 after purification was lower than that of other claws, the purity of the RNA was similar (Table 4). This result agrees with Hanly et al. (2009), who obtained, on average, $396 \pm$ $274 \mu \mathrm{g}$ of RNA/mL from laminae biopsy specimens of horses.

\section{Hoof Tissue Formation and Cell Growth}

Expression of $B T D$ and Krüppel-like factor 10 ( $K L F 10)$ was greater $(P=0.03)$ in claw 3 than in claw 5 . In the context of $B T D$, this suggested that claw 5 might have lower capacity to recycle available biotin (Table 5). A decreased supply of biotin to cells undergo- ing keratinization can result in decreased claw growth because synthesis of keratin and intercellular cement substance (ICS; Mülling et al., 1999), are biotin-dependent processes. The importance of biotin for the normal functioning of the bovine hoof has been demonstrated in studies that showed that supplemental dietary biotin increased the rate of growth of hooves (Bergsten et al., 2003; da Silva et al., 2010) and decreased the incidence of hoof pathology (Bergsten et al., 2003). Krüppel-like factor 10 has been associated with inhibition of cell growth, and its expression is induced by estrogen and transforming growth factor $\beta 1, \beta 2$, and $\beta 3$, as well as other growth factors (Hsu et al., 2011). The biological significance for lower mRNA expression of KLF10 in claw 5 and the extent of the effect of this protein within keratinocytes is unclear.

Among the keratins evaluated, KRT2, KRT4, KRT10, and KRT13 were present in the reference RNA sample but not in the hoof tissue. Although these keratin proteins were not expressed in our hoof tissue specimens, previous studies have reported expression of KRT4, KRT10, and KRT14 from the sole of the claw of 
Table 2. GenBank accession number, sequence, and amplicon size of primers used to analyze gene expression by quantitative PCR

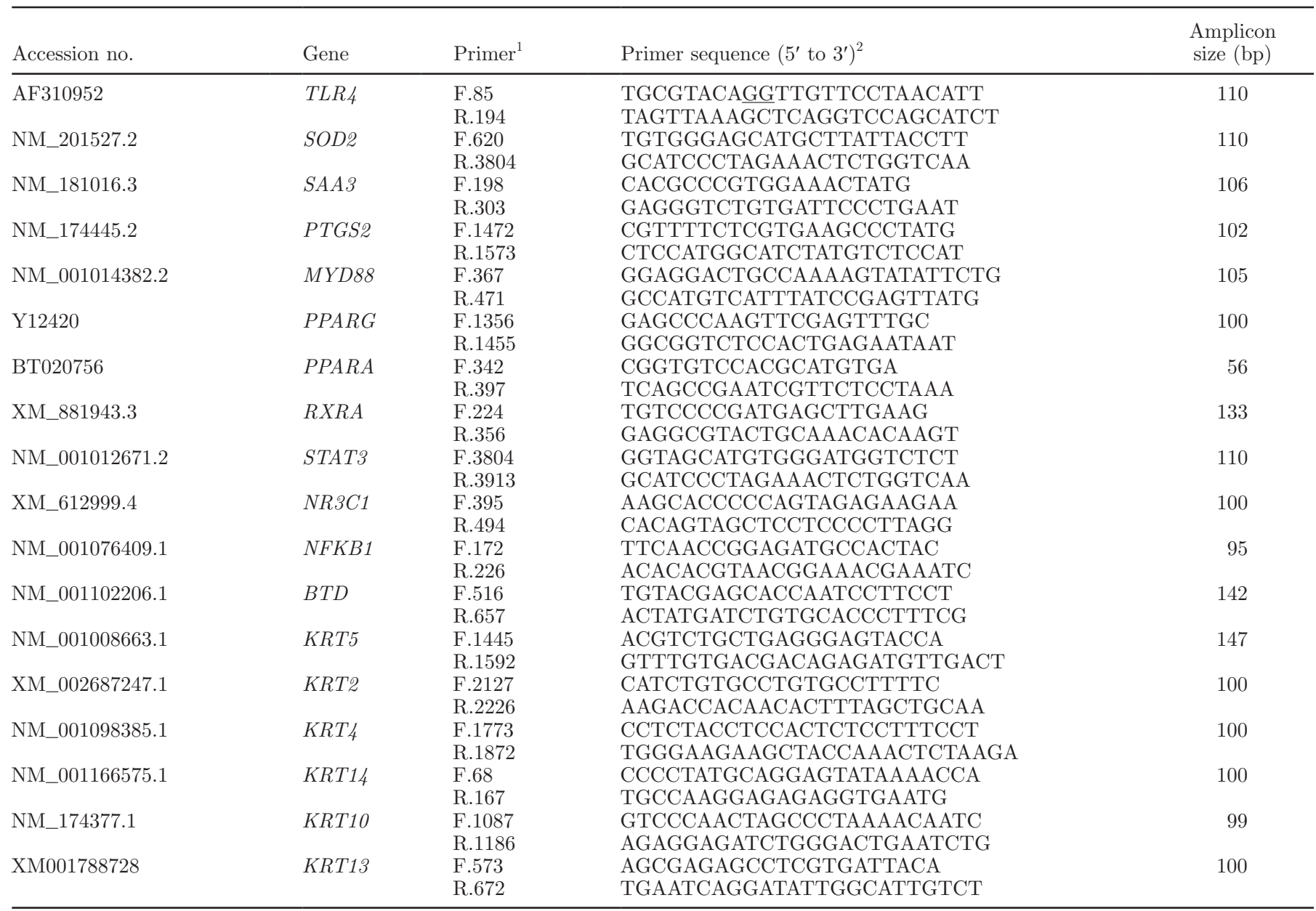

${ }^{1}$ Primer direction and hybridization position on the sequence.

${ }^{2}$ Exon-exon junctions are underlined.

bovine specimens by alternative techniques such as immunoblotting (Hendry et al., 2001). Analysis of qPCR data revealed that amplification of PTGS2, PPARG, and KRT14 required more than 30 cycles $(\mathrm{Ct})$ in order for the fluorescent signal to cross the threshold (i.e., exceed background level), which underscored their low abundance in hoof tissue. The amount of target nucleic acid in a biological sample is inversely correlated to $\mathrm{Ct}$

Table 3. Locomotion score (LS) assessment during $7 \mathrm{~d}$ following biopsy

\begin{tabular}{|c|c|c|c|c|c|}
\hline \multirow[b]{2}{*}{ Day } & \multicolumn{3}{|c|}{$\mathrm{LS}^{1}$} & \multirow{2}{*}{$\begin{array}{c}\mathrm{LS}>1 \\
\text { (\% of all cows) }\end{array}$} & \multirow{2}{*}{$\begin{array}{c}\mathrm{LS} \geq 3 \\
\text { (\% of all cows) }\end{array}$} \\
\hline & 1 & 2 & 3 & & \\
\hline 0 (prebiopsy) & 6 & 0 & 0 & 0 & 0 \\
\hline 1 & 1 & 5 & 0 & 83 & 0 \\
\hline 2 & 1 & 4 & 1 & 83 & 16 \\
\hline 3 & 2 & 3 & 1 & 67 & 16 \\
\hline 4 & 2 & 3 & 1 & 67 & 16 \\
\hline 5 & 2 & 4 & 0 & 67 & 0 \\
\hline 6 & 3 & 3 & 0 & 50 & 0 \\
\hline 7 & 6 & 0 & 0 & 0 & 0 \\
\hline
\end{tabular}

${ }^{1}$ Locomotion score of 6 cows based on Flower and Weary (2006), where locomotion score $1=$ smooth and fluid movement; 2 = imperfect locomotion but moves freely; $3=$ ability to move freely is compromised; $4=$ ability to move freely obviously diminished; $5=$ must be vigorously encouraged to move. 
Table 4. Yield and quality of RNA extracted from hoof specimens

\begin{tabular}{|c|c|c|c|c|}
\hline Position $^{1}$ & Tissue (mg) & $\mathrm{RNA}\left(\mu \mathrm{g} / \mathrm{mL}^{2}\right)$ & $\begin{array}{c}\text { RNA } \\
(\mu \mathrm{g} / \mathrm{mg} \text { of tissue })\end{array}$ & $260 / 280^{3}$ \\
\hline 3 & $92 \pm 27$ & $258 \pm 135$ & $260 \pm 100$ & 2.15 \\
\hline 5 & $126 \pm 49$ & $445 \pm 169$ & $448 \pm 289$ & 2.10 \\
\hline 7 & $65 \pm 3$ & $321 \pm 40$ & $496 \pm 118$ & 1.97 \\
\hline
\end{tabular}

cycles. Work in our laboratory has established that a threshold of 30 cycles (Piantoni et al., 2008) is optimal to consider target genes as being expressed (Table 6).

Keratin 5 (KRT5) was the only keratin expressed, based on our criterion, in tissue specimens (Table 6). Differences in expression of KRT5 between claws 3 and 5 did not reach significance $(P=0.14)$; however, when comparing the relative fold difference for KRT5 in each claw over that of claw 7 (nonsusceptible), expression for claw $3 / 7$ was slightly downregulated $(-1.09)$, whereas that of $5 / 7$ was more than 2 -fold greater (Table 5 ). Fold differences for KRT5 between claws 3 and 5 with respect to claw 7 could be related to an inherently lower degree of keratinization (claw $3 / 7$ ) or to increased tissue turnover activity (claw 5/7), which could render those claws susceptible, or not, to early onset of lameness. Hendry et al. (2001) found a lesser amount of KRT5 protein in sole corium ulcerated bovine claws than in healthy claws.

\section{Inflammatory Response and Oxidative Stress}

Greater expression $(P=0.06)$ of $R X R A$ in claws $3+$ 5 than in claw 7 (Table 5 ) could be related to inherently greater inflammatory and lipid metabolism activity in those claws. As such, these results seem to suggest that claws 3 and 5 may be more prone to development of laminitis. However, MYD88 expression in claws $3+5$ versus claw $7(P=0.51)$ and nonsignificant differences in expression of NFKB1 and TLR 4 suggested the presence of additional interactions coordinating the inflammatory response cascade. The nature of such interactions would have to be elucidated in future studies.

Although differences $(P=0.17)$ between claws $3+$ 5 versus claw 7 were modest for PPARA expression, it is important to note (Table 6) the marked differences in mRNA abundance between PPARA (4.1\%) and $P P A R G(0.1 \%)$. The latter has been associated with lipid synthesis in the bovine mammary gland (Bionaz

Table 5. $\log _{2}$-transformed expression profiles (95\% CI in parentheses) of genes associated with cell differentiation, proliferation, inflammation, and keratin formation in front and rear claws

\begin{tabular}{|c|c|c|c|c|c|c|c|}
\hline Gene & \multicolumn{3}{|c|}{ Claw position ${ }^{1}$} & 3 vs. $5^{2}$ & $3+5$ vs. $7^{3}$ & \multicolumn{2}{|c|}{ Fold difference $^{4}$} \\
\hline KRT5 & $0.33(0.19-0.57)$ & $0.78(0.51-1.20)$ & $0.36(0.21-0.61)$ & 0.14 & 0.65 & -1.09 & 2.18 \\
\hline$M Y D 88$ & $0.89(0.77-1.03)$ & $0.78(0.68-0.90)$ & $0.93(0.78-1.10)$ & 0.20 & 0.51 & -1.04 & -1.18 \\
\hline NFKB1 & $0.99(0.92-1.06)$ & $0.98(0.92-1.05)$ & $0.83(0.77-0.90)$ & 0.91 & 0.19 & 1.19 & 1.18 \\
\hline$P P A R G$ & $1.23(0.77-1.97)$ & $1.21(0.75-1.95)$ & $2.06(1.28-3.33)$ & 0.93 & 0.52 & -1.67 & -1.70 \\
\hline$R X R A$ & $1.09(0.99-1.21)$ & $1.08(0.98-1.18)$ & $0.72(0.65-0.81)$ & 0.87 & 0.06 & 1.51 & 1.49 \\
\hline$S A A 3$ & $0.98(0.92-1.04)$ & $0.98(0.93-1.03)$ & $1.06(0.99-1.13)$ & 0.90 & 0.41 & -1.07 & -1.08 \\
\hline SOD2 & $1.11(1.03-1.20)$ & $1.10(1.04-1.17)$ & $1.04(0.96-1.12)$ & 0.90 & 0.53 & 1.07 & 1.06 \\
\hline STAT3 & $1.03(0.93-1.15)$ & $0.99(0.90-1.09)$ & $1.10(0.97-1.24)$ & 0.40 & 0.64 & -1.06 & -1.11 \\
\hline TLR4 & $1.12(1.04-1.20)$ & $1.11(1.04-1.18)$ & $1.04(0.96-1.12)$ & 0.92 & 0.50 & 1.08 & 1.07 \\
\hline
\end{tabular}

${ }^{1}$ Back-transformed least squares means of relative mRNA expression (95\% confidence limits in parentheses), by claw position: front leg, right limb, medial claw (3); rear leg, left limb, lateral claw (5); rear leg, right limb, medial claw (7).

${ }^{2} P$-value associated with the contrast between claws 3 and 5 .

${ }^{3} P$-value associated with the contrast between susceptible claws $(3+5)$ and nonsusceptible claw $(7)$.

${ }^{4}$ Fold difference in mRNA expression of claw 3/mRNA expression in claw 7 and mRNA expression in claw $5 / \mathrm{mRNA}$ expression in claw 7 . Fold decrease was calculated as the negative inverse $(-1.0 / \mathrm{x})$ when the resulting value was $<1.0$. These data are for comparison only as no statistical analysis was performed. 
Table 6. Slope, coefficient of determination of the standard curve $\left(\mathrm{R}^{2}\right)$, efficiency of amplification, and median cycle threshold $(\mathrm{Ct})$ of quantitative reverse transcription-PCR

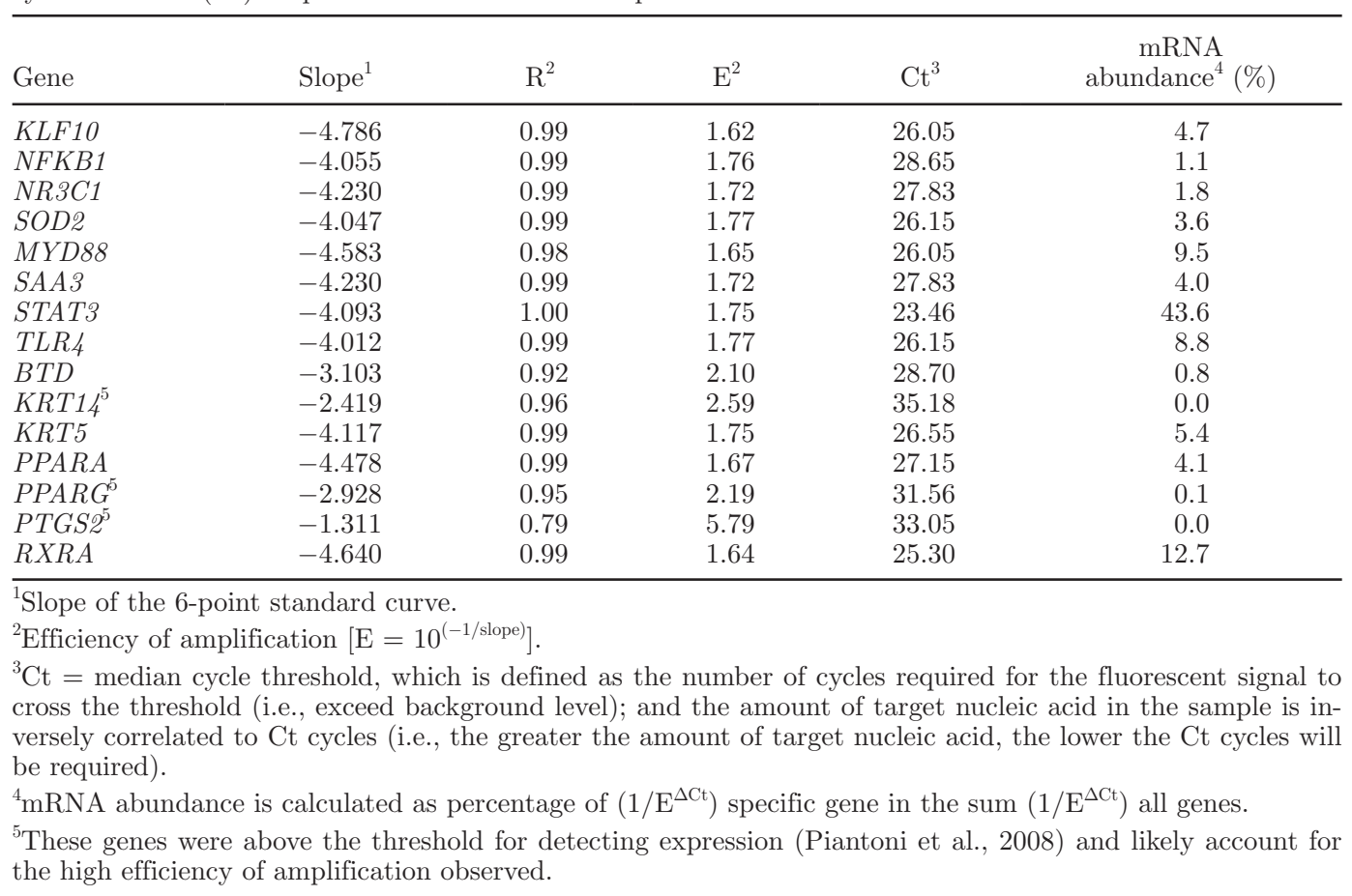

and Loor, 2008); thus, differential mRNA abundance of PPARA versus PPARG could have biological relevance in the context of the hoof; for example, ligand preference, as is the case for long-chain fatty acids or other endogenous eicosanoids (Bionaz et al., 2012). Because ICS is a lipid-rich material, intracellular lipid metabolism regulators such as PPAR and RXR might play an important role not only in ICS production but also potentially in degradation (e.g., PPARA). In this study, the difference in mRNA abundance between PPARA and PPARG would seem to favor lipid catabolism upon activation of the PPAR. Such a response would lead to a possible decrease in lipid-rich ICS, and consequently lower claw integrity in susceptible claws 3 and 5 .

Signal transducer and activator of transcription 3 (STAT3) mediates apoptosis during the acute-phase and inflammatory response initiated in liver (Pensa et al., 2009). Interestingly, STAT3 had the greatest mRNA abundance $(43 \%)$ of all genes measured, $>3$ times greater than RXRA mRNA, the second most abundant gene. In fact, genes related to the inflammatory response and oxidative stress accounted for $>83 \%$ of total mRNA measured in this study (Table $6)$. Together, these data seem to underscore the importance of these biological pathways in hoof tissue. More importantly, they provide additional clues on whether stressors such as floor surfaces, climate, and nutrition could modify normal cellular processes in hoof tissue and contribute to the onset of lameness. Although we observed no effect of claw position on STAT3 expression, the fold difference observed in claw $3 / 7$ was -1.06 , whereas that in $5 / 7$ was -1.11 , suggesting potentially greater activity of this transcription factor in claw 7 . Despite that finding, the nonsignificant expression of $S A A 3$ between claws was puzzling because $S A A 3$ is a direct target of STAT3 during the hepatic acute-phase response (Pensa et al., 2009). It is possible, however, that the link between STAT3 and SAA3 (and other inflammation-related genes) differs from what takes place in liver.

\section{CONCLUSIONS}

The biopsy technique described was suitable for harvesting hoof tissue from conscious animals for use in histologic and transcriptomics studies. The procedure caused only mild, transient changes in locomotion score in a small percentage of the animals; thus, it would be suitable for serial sample collection. This biopsy procedure yielded a reasonable amount of laminar tissue as well as sufficient purified RNA to perform qPCR. Although gene expression did not seem to differ markedly between claw positions, results provided evidence of inherent differences that might influence biotin availability and lipid metabolism. Differences among claw position in inflammatory response remain unclear. This 
procedure would be useful for mechanistic studies investigating the effects of changes in physiological state; for example, the peripartal period, on the tissue of the hoof and lameness. Future analysis of gene expression of hoof tissue would complement our current knowledge of the mechanisms relating environmental and dietary factors to lameness.

\section{REFERENCES}

Bailey, S. R., H. S. Adair, C. R. Reinemeyer, S. J. Morgan, A. C. Brooks, S. L. Longhofer, and J. Elliott. 2009. Plasma concentrations of endotoxin and platelet activation in the developmental stage of oligofructose-induced laminitis. Vet. Immunol. Immunopathol. 129:167-173.

Bergsten, C., P. R. Greenough, J. M. Gay, W. M. Seymour, and C. C. Gay. 2003. Effects of biotin supplementation on performance and claw lesions on a commercial dairy farm. J. Dairy Sci. 86:39533962 .

Bionaz, M., and J. J. Loor. 2007. Identification of reference genes for quantitative real-time PCR in the bovine mammary gland during the lactation cycle. Physiol. Genomics 29:312-319.

Bionaz, M., and J. J. Loor. 2008. Gene networks driving bovine milk fat synthesis during the lactation cycle. BMC Genomics 9:366387.

Bionaz, M., B. J. Thering, and J. J. Loor. 2012. Fine metabolic regulation in ruminants via nutrient-gene interactions: Saturated longchain fatty acids increase expression of genes involved in lipid metabolism and immune response partly through PPAR-alpha activation. Br. J. Nutr. 107:179-91.

Capion, N., S. M. Thamsborg, and C. Enevoldsen. 2008. Conformation of hind legs and lameness in Danish Holstein heifers. J. Dairy Sci. 91:2089-2097.

da Silva, L. A., L. G. Franco, I. B. Atayde, P. H. da Cunha, M. I. de Moura, and D. S. Goulart. 2010. Effect of biotin supplementation on claw horn growth in young, clinically healthy cattle. Can. Vet. J. 51:607-610.

Danscher, A. M., J. M. Enemark, E. Telezhenko, N. Capion, C. T. Ekstrom, and M. B. Thoefner. 2009. Oligofructose overload induces lameness in cattle. J. Dairy Sci. 92:607-616.

Faleiros, R. R., B. S. Leise, M. Watts, P. J. Johnson. S. J. Black, and J. K. Belknap. 2011. Laminar chemokine mRNA concentrations in horses with carbohydrate overload-induced laminitis. Vet. Immunol. Immunopathol. 144:45-51.

Flower, F. C., and D. M. Weary. 2006. Effect of hoof pathology on subjective assessment of dairy cow gait. J. Dairy Sci. 89:139-146.

Graugnard, D. E., L. L. Berger, D. B. Faulkner, and J. J. Loor. 2010. High-starch diets induce precocious adipogenic gene network upregulation in longissimus lumborum of early-weaned Angus cattle. Br. J. Nutr. 103:953-963.

Hanly, B. K., A. M. Stokes, A. M. Bell, J. R. Johnson, M. L. Keowen, D. B. Paulsen, G. A. Sod, and R. M. Moore. 2009. Use of serial laminar tissue collection via biopsy in conscious healthy horses. Am. J. Vet. Res. 70:697-702.

Hendry, K. A., A. J. MacCallum, C. H. Knight, and C. J. Wilde. 1997. Laminitis in the dairy cow: A cell biological approach. J. Dairy Res. 64:475-486.

Hendry, K. A., A. J. MacCallum, C. H. Knight, and C. J. Wilde. 2001. Synthesis and distribution of cytokeratins in healthy and ulcerated bovine claw epidermis. J. Dairy Res. 68:525-537.
Hsu, C. F., C. L. Sui, W. C. Wu, J. J. Wang, D. H. Yang, Y. C. Chen, W. C. Yu, and H. S. Chang. 2011. Klf10 induces cell apoptosis through modulation of BI-1 expression and $\mathrm{Ca}^{2+}$ homeostasis in estrogen-responding adenocarcinoma cells. Int. J. Biochem. Cell Biol. 43:666-673.

Leise, B. S., R. R. Faleiros, M. Watts, P. J. Johnson, S. J. Black, and J. K. Belknap. 2011. Laminar inflammatory gene expression in the carbohydrate overload model of equine laminitis. Equine Vet. J. 43:54-61.

Loor, J. J., H. M. Dann, R. E. Everts, R. Oliveira, C. A. Green, N. A. Guretzky, S. L. Rodriguez-Zas, H. A. Lewin, and J. K. Drackley. 2005. Temporal gene expression profiling of liver from periparturient dairy cows reveals complex adaptive mechanisms in hepatic function. Physiol. Genomics 23:217-226.

Mills, J. A., D. S. Zarlenga, P. L. Habecker, and R. M. Dyer. 2009. Age, segment, and horn disease affect expression of cytokines, growth factors, and receptors in the epidermis and dermis of the bovine claw. J. Dairy Sci. 92:5977-5987.

Muggli, E., C. Sauter-Louis, U. Braun, and K. Nuss. 2011. Length asymmetry of the bovine digits. Vet. J. 188:295-300.

Mülling, C., H. Bragulla, S. Reese, K. D. Budras, and W. Steinberg, 1999. How structures in bovine hoof epidermis and influenced by nutritional factors. Anat. Histol. Embryol. 28:103-108.

Neveux, S., D. M. Weary, J. Rushen, M. A. von Keyserlingk, and A. M. de Passille. 2006. Hoof discomfort changes how dairy cattle distribute their body weight. J. Dairy Sci. 89:2503-2509.

Norring, M., E. Manninen, A. M. de Passillé, J. Rushen, L. Munksgaard, and H. Saloniemi. 2008. Effects of sand and straw bedding on the lying behavior, cleanliness, and hoof and hock injuries of dairy cows. J. Dairy Sci. 91:570-576.

Omary, M. B., N. O. Ku, P. Strand, and S. Hanada. 2009. Toward unraveling the complexity of simple epithelial keratins in human disease. J. Clin. Invest. 119:1794-1805.

Pensa, S., C. J. Watson, and V. Poli. 2009. Stat3 and the inflammation/acute phase response in involution and breast cancer. J. Mammary Gland Biol. Neoplasia 14:121-129.

Piantoni, P., M. Bionaz, D. E. Graugnard, K. M. Daniels, R. M. Akers, and J. J. Loor. 2008. Gene expression ratio stability evaluation in prepubertal bovine mammary tissue from calves fed different milk replacers reveals novel internal controls for quantitative polymerase chain reaction. J. Nutr. 138:1158-1164.

Singh, S. S., W. R. Ward, and R. D. Murray. 1993. Technique of hoof biopsy in cattle. Vet. Rec. 133:190-191.

Singh, S. S., W. R. Ward, and R. D. Murray. 1994. Gross and histopathological study of endotoxin-induced hoof lesions in cattle. J. Comp. Pathol. 110:103-115.

Tomlinson, D. J., C. H. Mulling, and T. M. Fakler. 2004. Invited review: Formation of keratins in the bovine claw: Roles of hormones, minerals, and vitamins in functional claw integrity. J. Dairy Sci. 87:797-809.

Toussiant, R. E. 1989. Cattle Foot Care and Claw Trimming. The Farming Press, Ipswich, UK.

US Department of Agriculture. 2007. Part I: Reference of Dairy Cattle Health and Management Practices in the United States. USDAAPHIS-VS, CEAH. N480.1007.2007. USDA, Washington, DC.

van der Tol, P. P., J. H. Metz, E. N. Noordhuizen-Stassen, W. Back, C. R. Braam, and W. A. Weijs. 2002. The pressure distribution under the bovine claw during square standing on a flat substrate. J. Dairy Sci. 85:1476-1481. 